\title{
OECDpublishing
}

\section{INCENTIVES AND CONSTRAINTS OF INFORMAL TRADE BETWEEN NIGERIA AND ITS NEIGHBOURS}

\section{WEST AFRICAN PAPERS}

July 2018 No. 16

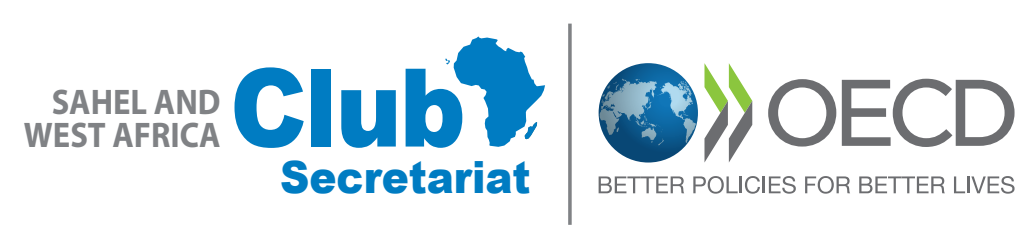





\section{INCENTIVES AND CONSTRAINTS OF INFORMAL TRADE BETWEEN NIGERIA AND ITS NEIGHBOURS}

This paper has been prepared by

LEENA KONI HOFFMANN

PAUL MELLY

Chatham House 


\section{WEST AFRICAN PAPERS}

The West African Papers series explores African socio-economic, political and security dynamics from a regional and multidisciplinary perspective. It seeks to stimulate discussion and gather information to better anticipate the changes that will shape future policies. The series is designed for a wide audience of specialists, development practitioners, decision makers and the informed public. Papers are available in English and/or French, and summaries are available in both languages. Initiated by the Sahel and West Africa Club (SWAC) to highlight and promote West African issues, the work presented is prepared by its Secretariat, Members and partners, other OECD departments, related international organisations, associated experts and researchers.

Please cite this publication as:

Hoffmann, L.K. and P. Melly (2018), "Incentives and constraints of informal trade between Nigeria and its neighbours", West African Papers, N¹6, OECD Publishing, Paris.

https://doi.org/10.1787/7aa64379-en

Authors'contact:lhoffmann@chathamhouse.org \& paulmelly@fastmail.net

ISSN 2414-2026

OECD Working Papers should not be reported as representing the official views of the OECD or of its member countries. The opinions expressed and arguments employed are those of the authors.

This document and any map included herein are without prejudice to the status of or sovereignty over any territory, to the delimitation of international frontiers and boundaries and to the name of any territory, city or area.

Working Papers describe preliminary results or research in progress by the author(s) and are published to stimulate discussion on a broad range of issues on which the OECD works. Comments on Working Papers are welcomed, and may be sent to the Sahel and West Africa Club, OECD, 2 rue André-Pascal, 75775 Paris Cedex 16, France.

Authorised for publication by Laurent Bossard, Director, Sahel and West Africa Club Secretariat (SWAC/OECD).

\section{(C) OECD 2018}

You can copy, download or print OECD content for your own use, and you can include excerpts from OECD publications, databases and multimedia products in your own documents, presentations, blogs, websites and teaching materials, provided that suitable acknowledgment of OECD as source and copyright owner is given. All requests for commercial use and translation rights should be submitted to rights@oecd.org. 


\begin{abstract}
The scale of unrecorded trade across the border between Nigeria, the region's biggest economy and market, and its francophone neighbours is particularly high. Despite providing economic incentives, informal trade entails costs, complications and sometimes risks. This paper explores how policy choices and government actions continue to drive informality and the critical steps that might be taken to create a business environment that is more conducive and supportive of trade between West African neighbours on a formal basis. It goes on to examine the steps that have been taken since 2015 regarding trade promotion by West African states and considers the options for further policy action and public investment.
\end{abstract}

Keywords: informal trade, trade network, regional markets, regional integration, border co-operation JEL Classification: F1, F4, O1, Q1

\title{
ABOUT THE AUTHORS
}

Leena Koni Hoffmann is a researcher and associate fellow of the Africa Programme at Chatham House. She was a Marie Curie research fellow at the Luxembourg Institute of Socio-Economic Research (LISER) in 2013-15. Her research focuses on Nigeria's politics, corruption, governance issues, regional security and trade in West Africa. Paul Melly, an associate fellow of the Africa Programme at Chatham House, is a researcher and journalist who focuses on sub-Saharan development themes and the politics of francophone countries. He takes a special interest in West African regional issues and the role of international partners.

\section{NOTE TO READERS}

The authors gratefully acknowledge Olivier Walther and Joan Nimarkoh for their careful editorial review. The views expressed herein are the responsibility of the authors alone.

This Note is published as part of the partnership between SWAC/OECD and the Sahel Research Group of the University of Florida. The collaboration aims to:

1. Reinforce ties between research and policies for sustainable development that can help better anticipate changes within the Sahel and West Africa region.

2. Promote West African expertise by reinforcing the links with African researchers and research centres through the Sahel Research Group network.

\section{THE SAHEL AND WEST AFRICA CLUB}

The Sahel and West Africa Club (SWAC) is an independent, international platform. Its Secretariat is hosted at the Organisation for Economic Co-operation and Development (OECD).

SWAC's mission is to promote regional policies that will improve the economic and social well-being of people in the Sahel and West Africa. Its objectives are to:

- Improve the regional governance of food and nutrition security.

- Improve the understanding of ongoing transformations in the region and their policy implications through regional, spatial and forward-looking analyses.

SWAC Members are: Austria, Belgium, Canada, CILSS, the ECOWAS Commission, the European Union, France, Luxembourg, the Netherlands, Switzerland, the UEMOA Commission and the United States.

Germany, Israel, the Network of Farmers' Organisations and Agricultural Producers of West Africa (ROPPA), Norway, Spain, the United Kingdom and the World Bank participate in SWAC meetings as Observers.

SWAC has memorandums of understanding with the NEPAD Agency and the University of Florida (Sahel Research Group).

For more information: wWW.oecd.org/swad. 


\section{TABLE OF CONTENTS}

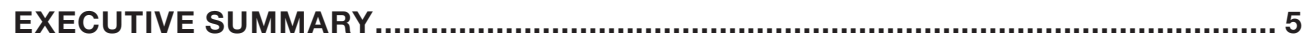

A REALISTIC APPROACH TO THE SCALE AND DIVERSITY OF TRADE IN WEST AFRICA AND NIGERIA ..................................................................................... 6

EXPLORING CROSS-BORDER TRADE REALITIES................................................... 8

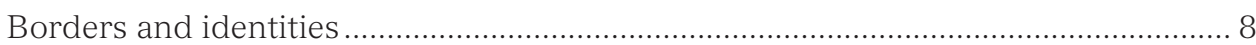

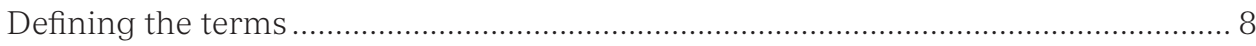

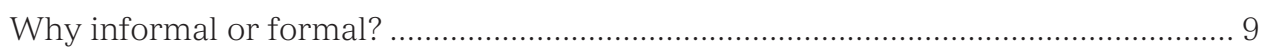

Geographical and economic factors influencing informal trade ......................... 10

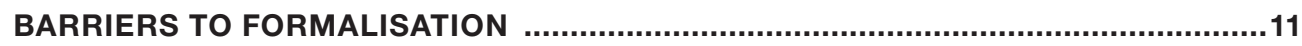

Finance and banking regulations in West Africa............................................... 11

International payments between Nigeria and its neighbours................................ 11

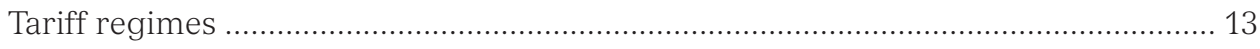

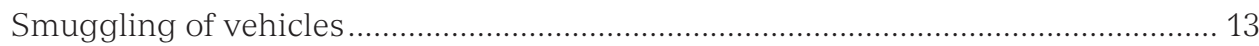

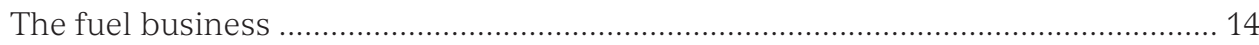

Food production, trade policy and tariffs in Nigeria: The example of rice ............. 15

STRENGTHENING NIGERIA AND NEIGHBOURING COUNTRIES' BUSINESS-

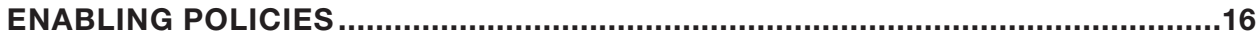

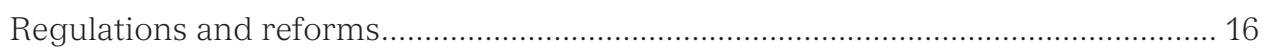

Insufficient public investment in public goods and services .............................. 16

The role of port infrastructure and efficiency in international trade........................ 17

Land transport infrastructure and connectivity in trade .................................... 18

Land border procedures and informality .......................................................... 18

POLITICAL PERSPECTIVES .......................................................................................19

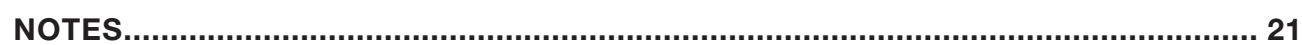

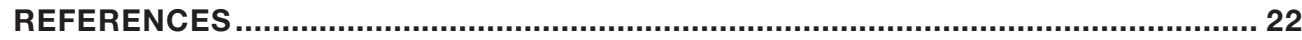




\section{EXECUTIVE SUMMARY}

W

est Africa's porous national borders host major trading points for immense market activity and movement in goods and people, providing a critical interchange for informal cross border networks. Official figures for this trading activity give only a partial picture of the huge informal flow of goods across the region's porous borders, and particularly between Nigeria, much the biggest member of the Economic Community of West African States (ECOWAS), and its neighbours Benin and Niger. Although formally unrecorded, this represents an enormous volume of activity, and a major contributor to employment and prosperity. This gap between official numbers and reality has big implications for West African governments' formulation of trade and development policy.

A 2015 report published by the think-tank Chatham House examined the factors that drive this officially unrecorded trade and constrain the scope for it to become more formalised. Subsequent years have seen some changes in the economic environment, government policies and the business context. In this West Africa paper, the authors of the 2015 study examine these developments and their impact on the environment for informal crossborder trade between Nigeria and its neighbours, and the wider West African trading context. Building on previous studies undertaken, the paper features research from extensive fieldwork on border networks in Benin, Niger and Nigeria; and contributes to ongoing debates on the potential role of informal trade as a catalyst for inclusive growth.

The characteristics and growth of informal cross-border trade reflect the stark reality of West Africa's geography, climate and socio-economy. Its scale however, reflects current governance realities and the policy choices made by governments and banking authorities. Government policies play a major role in sustaining demand for informal goods as consumers reacts to price volatility caused by subsidies, imports ban and related export restrictions. And bureaucratic hurdles, differences in national fiscal policies and contrasts between ports in terms of cost and efficiency have also helped to nudge trade into informal channels. The inability of central banks in the region to adjust regulation of exchange to allow commercial banks to offer small traders low-cost services for direct cross-border payments from naira to CFA franc and vice-versa has been a major barrier to formal trade. The continued high costs of operating within formal trade markets, particularly burdensome for micro-small and medium scale traders have also been a critical driver.

The past two and a half years have brought some significant changes to this environment. A rise in world oil prices and changes to Nigerian policy on fuel pricing have partially reshaped the environment that sustains fuel smuggling to Benin, while a sharp tightening of Nigerian policy on the import of cars has also made itself felt. Steps have been taken to improve the efficiency of border controls, marginally reducing the hassle of formal trading across this frontier, and the gradual implementation of an ECOWAS single external tariff is eroding the tariff differential that encouraged Nigerian importers to land goods in Cotonou, Benin. Yet non-tariff barriers are pushing in the opposite direction and other major disincentives to formalisation persist, particularly for locally produced products. Government regulation still prevents banks offering the rapid low-cost CFA/ naira payment services that small business need. Two years after the authors' original study, administrative procedures still complicate matters and remain a major driver of the region's informal economy. 


\section{Strengthening Nigeria and neighbouring countries' business-enabling policies}

Despite the considerable challenges, a number of policy options are available to strengthen trade promotion between Nigeria and neighbouring countries.

Nigeria should break from trade policy-thinking that depends on protectionist measures and import restrictions and develop a more creative approach, giving particular priority to the encouragement of cross-border export and import trade with its neighbours in ECOWAS.

Central banks should permit - and encourage - commercial banks to provide simple electronic services for direct CFA-naira payments. This would give small traders an incentive to use safer, officially regulated banking channels for cross-border business transactions.

More integrated one-stop border posts should be established at Nigeria's key frontier crossings with Niger and Benin. And business facilities for SME and market traders should be improved at these border crossings, to help traders complete the formalities quickly.

Focus should also rest on stimulating Nigeria's dynamic local businesses to build an enabling regulatory environment that supports growth within formal rather than informal markets. Providing incentives for SMEs to shift towards the formal sector should be key to the government's approach, such as the provision of power alongside key business and financial services.

Lastly, the development of port, road and rail projects has often been impeded by political, planning or business issues. The governments of Nigeria, Niger and Benin should identify key schemes as national priorities and seek to facilitate their early completion.

\section{A REALISTIC APPROACH TO THE SCALE AND DIVERSITY OF TRADE IN WEST AFRICA AND NIGERIA}

he common view of West African trade flows is that raw or minimally processed
commodities flow out to the "North", while value-added technology, manufactured
consumer goods and even basic foodstuffs flow back in. According to official data, West
Africa's exports to the rest of the world - oil, gold, diamonds, cocoa, coffee, cotton,
bananas, groundnuts - are mostly raw or slightly processed. Manufactured consumer
products, vehicles, capital equipment and food commodities such as rice or even frozen
chicken, mainly come from Western countries or major emerging economic powers such as
China, Brazil or even Thailand. This is the picture mostly painted by official trade figures
for West Africa and it is a discouraging vision - a pattern of international exchange that,
in essence, has changed little since the era before independence.

The picture of unequal trade which emerges from official trade figures is discouraging and often cited in critiques of the dangers of asymmetric globalisation (Birdsall, 2003) and patterns of international exchange that have been slow to change since the 1980s and 1990s when more developing countries opened and liberalised their markets. In contrast to their East Asian counterparts, West African economies have mostly not managed to make the transition from primary production, with little value added, to internationally competitive manufacturing, value addition and large-scale formalised employment.

Yet this image is an incomplete representation of West Africa's international trade, one that obscures the complex and diverse reality of flourishing informal economic activity across regional borders. The cross-border trading landscape within West Africa is a vast phenomenon that is largely unmeasured and unregulated by national governments and is therefore barely documented in official statistics (Chatham House, 2015). In fact, 
this feature of informality is common across Africa and is estimated to make up almost $40 \%$ of the continent's GDP if not more. These dynamic trends in supply and demand are shaped and calibrated by regional contrasts in climate, production, population, industrial or agricultural strength, and by strengths or weaknesses in infrastructure and administration and the decisions of politics and public policy.

Today there is a growing recognition of the dynamism of intra-regional economic activity in West Africa and the role that it plays as a source of livelihoods and overall prosperity. There is also an increasing urgency in the debate over how trade can fuel and support development, particularly in developing regions such as West Africa. In recent years, the trade and development discourse has become more regionally and even more locally focused, examining the dynamics of economic activity from a grassroots perspective. This raises the question of how largely informal cross-border business might become more efficient and might more powerfully drive overall economic growth development if the factors that hamper trade and add to its costs were relaxed or even removed. A locallyoriented focus provides a critical opportunity to better understand the complex reality of flourishing trade across borders within West Africa and the diverse range of factors that shape these trade movements.

The contrast between officially measured trade with the wider world and the huge volumes of unregulated and unrecorded sub-regional traffic across borders is particularly striking in the case of Nigeria, by far the largest economy and society in ECOWAS. The first aim of this analysis is therefore to examine a range of key regulatory, governance and infrastructure-related constraints and pressures that erode traders' ability and willingness to formalise cross-border trade activities — and the factors that could foster increased formalisation of trade. The paper also assesses ongoing efforts to promote more formal external trade between Nigeria and its regional trade partners within the evolving regional project of economic integration. As informal trade entails costs, complications and sometimes risks (Walther 2015), it is thus worth exploring the critical steps that might be taken to create a business environment which is more conducive and supportive of trade between West African neighbours on a formal basis.

Building on an earlier report rooted in extensive field research in Benin, Niger and Nigeria (Chatham House 2015), the paper also seeks to take stock and examine how the trading environment has evolved since 2015. In 2015, West Africa was starting to introduce significant changes in the fiscal and regulatory framework for regional trade. Important infrastructure projects affecting trade were in the planning or the early stages of development, and progress can now be assessed. Moreover, the impact of the 2014 fall in oil prices has subsequently generated major impacts on the economic and monetary context for trade between Nigeria, the continent's biggest oil producer, and its West African neighbours. To assess progress, this paper will examine how the trading context has been influenced by the government actions taken in 2016 and 2017, regional decision-making and implementation mechanisms, infrastructure investment and economic circumstances. The discourse in this paper will seek answers to two key questions: How has the regional environment been improved to encourage more of Nigeria's trade with its ECOWAS neighbours to take place on formal terms with more officially recorded transactions? Also, what do current policy choices and government actions by regional decision makers tell us of their understanding informality?

Finally, the last section advocates critical measures that could provide easier and more supportive conditions for cross-border trade, and particularly formalised cross-border trading activities by small- and medium-sized enterprises (SMEs). 


\section{EXPLORING CROSS-BORDER TRADE REALITIES}

\section{Borders and identities}

t is crucial to understand the evolution of borders and geography in West Africa. Modern

national boundaries were determined and delineated in the colonial era and early postindependence years — roughly between 1880 and 1970 (Asiwaju and Adeniya, 1989). They were recognised by Heads of State and Government of the Organization of African Unity (OAU) meeting, held in Cairo, Egypt, in July 1964. These recognised boundaries are not necessarily coterminous with the underlying pattern of ethnic and social identities, or natural patterns of geography, climate and economic production.

This is particularly the case for Nigeria, where trade crosses the border both on a large scale and at the micro-informal community level and where underlying ethno-cultural affinities also straddle the formally drawn boundary lines of the Nigerian state.

In the north, there are long-established economic ties between Kano and Katsina and the adjacent Maradi region of south-central Niger, and the entire region has been at the heart of the wider Hausa ethnic and cultural space for hundreds of years. This is a region with a long history of trade and kinship connections that blend communities living on either side of the land border between the separate modern states of Nigeria and Niger (Miles, 2015).

Meanwhile, southwestern Nigeria and southeastern Benin share deep Yoruba cultural and ethnic affinities, stretching back centuries before the era of today's modern national borders (Omoniyi, 2004). Here too there is a flourishing trading culture, with goods and people moving back and forth across long-established trade corridors and routes.

Beyond these historical and cultural factors are the realities of modern state resources, both administrative and security-related. Even Nigeria, with by far the largest economy and bureaucratic architecture in West Africa, lacks the resources to effectively monitor and manage most of the length of its 4047 kilometre national land border and 852 kilometre coastline. All the country's neighbours including Cameroon in the southeast and Chad in the northeast are much less well-resourced and far less-equipped.

As in the rest of West Africa, national borders are completely porous and transnational economic activity and human movement are a fact of life. Nigeria officially operates 84 border control posts at the key border crossing points on main roads, such as Sémé border, on the highway between Lagos and Cotonou in the southwest, or Ilela/Birnin N'Konni, on the route from Sokoto (Nigeria) into Niger in the northwest. However, these official border control posts are dwarfed in number by over 1499 illegal or unauthorised routes in and out of the country.

Given the region's geographic and economic realities, the national government must make hard choices about where and how to deploy the limited border resources they do have. So, where they do seek to monitor movements through secondary routes, informal tracks or coastal creeks, their priority necessarily is the control of territorial threats or large-scale criminality. For obvious reasons of national interest, the disruption of routine local trade that happens to be informal ought to be a secondary concern for security and border management agencies, compared with serious security priorities.

\section{Defining the terms}

Formal cross-border trade entails the movement of goods into or out of a country through channels that are subject to official control or oversight, usually with some form of declaration to the government authorities on both sides of a border about the consignment in transit. The regulatory framework which requires that the movement of goods or livestock is reported to government agencies, provides an opportunity for the state to inspect the 
merchandise, carry out veterinary checks on live animals or ensure that health, hygiene, safety or other technical requirements are being complied with.

The conventional expectation is that the formal registration and supervision of business transactions can also provide an opportunity to raise revenue, through customs duties or tariffs, or other forms of tax, fees or levies. But the scope to impose revenue measures may of course be constrained by bi- or multilateral trade agreements between two or more countries. For example, under the ECOWAS Trade Liberalization Scheme (ETLS), trade in food products within the 15-country ECOWAS bloc should not be subject to tariffs and duties, other than a minimal administration fee. ${ }^{1}$

All cross-border traffic that is not formal is, in the strict sense of the term, "informal". The World Bank (2001) defines informal trade as "unorganized small scale trade which does not appear in the customs record". However, such trade activities may be "official" to the extent that "traders go through official border posts, pay a crossing fee to the immigration office, and if processed appropriately pay a duty on imports" (ibid.). This broad term is often mistakenly used to imply two sharply different types of activity. On the one hand, there is the movement of goods that states regard as illicit or dangerous, for example, ivory, weapons and narcotics, and thus subjected to strict trade regulatory regimes if they are not banned outright. On the other hand, there is the movement of legitimate goods but by informal means. Policymakers and state actors tend to assume a link between trade in illicit goods and informal cross-border trade or assume the terms "illicit" and "informal" are interchangeable. While the trade or traffic of both dangerous and routine goods happens informally, there is no clear or consistent evidence of any structural links between, for instance, terrorists or arms smugglers and informal cereals traders.

The type of cross-border trade involving legitimate goods but through informal channels or informally through official border crossings is a crucial driver of economic growth and a key source of employment and poverty reduction in both rural and urban communities, contributing to the dynamism of production systems. A key feature of the trading environment in West Africa is that a large proportion of the goods produced intraregionally as well as brought in from across the world, are exchanged in partially or wholly informal transactions. This type of economic activity is, however, greatly misunderstood by policymakers which sometimes leads to decisions and actions that impede rather than facilitate the formalisation of trade relations in the region.

The vibrancy of the informal domestic business scene inevitably feeds into a naturally dynamic flow of goods, people and animals across borders. This is also often poorly understood and fails to take account of the scale of informal activity, both domestic and cross-border, and its importance as a source of prosperity and livelihoods. Few governments in the region have given much priority to developing forms of regulation that might provide adequate and realistic oversight for the activity that is currently informal, without either suffocating it or pushing it back into informality.

\section{Why informal or formal?}

Informal cross-border trade is either viewed as disorderly business transactions that occur at the margins of the real economy or a dysfunction that needs to be curtailed because of the phenomenon's impact on government revenue collection and the difficulties of measuring trade that takes place through unregulated channels. In the case of Nigeria and Niger, informal trade accounts for more than half of economic activity along the 1497 kilometre land border between both countries.

Estimates of the scale of informal trade between Nigeria and its ECOWAS neighbours are hard to make, and not only because the borders are porous and unmonitored. The critical point is that activity in West African economies is a blend of formality and informality, with large areas of overlap. Aspects of typical village or market economic life are almost 
totally informal, unmeasured and operating outside the framework of clear data or financial accounts, but in other respects, even grassroots activity may be carefully monitored - for example, Niger's system for monitoring food crisis risks or Nigeria's agricultural extension advisory services. The overall picture is one where some villages have a close engagement with government services, others less so.

The dynamic trading economy in Cotonou, Benin, combines the carefully verified process of importing formally through the port's container terminals with the largely informal and unsupervised breaking down and repackaging of freight consignments in the city's warehouses and backstreets for onward passage to markets over the border into Nigeria. ${ }^{2}$

\section{Geographical and economic factors influencing informal trade}

Across the region, the characteristics of informal trade flows reflect West Africa's geographical, climatic and economic realities. For example, the Sahel is well suited to pastoralism and livestock rearing, while there is a large consumer demand for meat in urban markets along the coast, and more generally in Nigeria — which has a population currently estimated at 187 million. ${ }^{3}$ Some of the livestock is moved "on the hoof" as live animals from Niger and other Sahelian countries southwards to the coastal markets, and while increasing channels and volumes of this trade is monitored, ${ }^{4}$ much is informal. It is often partially formalised due to veterinary checks and certification but transactions with Nigerian buyers take place on less formal terms.

Meanwhile, grain from northern Nigeria's cereal-growing belt moves in the opposite direction, into Niger and other Sahelian countries where the climate risks to harvests are greater and production is necessarily less reliable. At the same time, farmers in Benin produce more grain than home demand requires, selling a substantial surplus into Nigeria, much of it moving informally direct to urban consumption centres without official oversight.

Beninese pineapples are also mostly sold to the populous eastern neighbour while onions from Niger are sold in coastal markets. Besides agricultural produce, fuel from Nigeria where prices have historically been subsidised — is smuggled into Benin and even Togo for sale in the informal market.

Beyond climate and farming complementarities and cycles, informal trade flows are driven by the state of infrastructure and national trade regimes in the region. In the case of Nigeria, its seaports have notably struggled to match the lower costs and efficiencies of Cotonou and Lomé. Additionally, government decisions on trade policy have had the effect of encouraging some suppliers to land goods in other countries before exporting into Nigeria (Torres and Jeske van Seters, 2016).

International economic factors, regulatory costs, governance issues and infrastructure gaps and competitiveness are all drivers behind informal flows of goods that sometimes originate from far outside the West African region but then circulate through informal routes. Government decisions such as the imposition of bans or restrictions on goods like rice or pasta have contributed to informalisation and created a well-entrenched market, particularly for smuggled rice, which meets the huge demand for the product that as yet cannot be satisfied through local production alone.

Alongside these factors, the sheer difficulty or cost of operating through official procedures for trade or payment has acted as a critical driver of informality, particularly for the thousands of smaller businesses and small-scale traders selling goods on a micro to smallscale basis to communities just across the border. Equally critical is the effect of restrictions by central bank regulation of cross-border payments and trade-related government administrative requirements on the ability of traders to operate formal businesses. 
As noted in 2015, interactions between Nigeria and the West African Economic and Monetary Union's (UEMOA) sub-regions monetary regimes have persistently discouraged micro-, small- and medium-sized West African businesses from formalising.

\section{BARRIERS TO FORMALISATION}

- or West African countries, an increase in formal business activity could generate more - revenue for governments, but formalisation is more valuable to the region as a tool for other areas of policy, such as product safety, value-addition and overall productivity. Formalisation can also provide more information for evidence-based policy-making. Yet, for formalisation to be a viable option for cross-border businesses it must provide tangible business incentives such as access to government financial support or technical advice, and translate into simpler and less burdensome procedures.

\section{Finance and banking regulations in West Africa}

The governance framework for trade and monetary exchanges, as it currently continues to function across West Africa, is not fully optimised and adapted to the region's cross-border dynamics (Hashim and Meagher, 1999; Gyimah-Brempong, Johnson and Takeshima, 2016). The CFA franc - the common currency of Benin, Niger and six other member states of UEMOA is pegged to the euro. Until mid-2016 the naira, Nigeria's national currency, was closely influenced by the dollar, due to the deliberate policy of the Central Bank of Nigeria (CBN) of maintaining a high degree of monetary stability (Christensen and Upper, 2017:8).

However, the 2014 fall in the price of oil, which accounts for more than $90 \%$ of foreign exchange earnings and $80 \%$ of government revenue, has exerted steadily growing pressure on the Nigerian economy and balance of payments. The Nigerian government's determination and efforts from 2015 into 2016, to maintain a strong local currency has served to hold down the cost of imported consumer goods for those consumers that could afford them. However, these efforts inadvertently hampered the diversification of the economy from oil and did not contribute to stimulating other sectors catering for both domestic and international demand.

In response to criticisms of Nigeria's monetary policy tightening, in June 2016, the CBN altered its stance, allowing the naira to float more freely. The currency quickly sank from CFA 2.90 to CFA 2 - a level that more accurately reflected the true level of investor confidence in a Nigerian economy hit hard by low oil prices.

This has had a major impact on both formal and informal cross-border trade with Benin, because Nigerians have seen their buying power dramatically reduced. At an informal level, Nigerian consumers increasingly insist on paying only in naira, because they do not want to risk changing their money into CFA francs, since the latter currency has been relatively strengthened.

These changed conditions have acted as a serious damper on trade, depressing economic activity for Beninese traders in markets at the Sémé-Kraké border crossing and for merchants in the markets in Cotonou.

\section{International payments between Nigeria and its neighbours}

The difficulty of making legitimate formal trade payments at low cost between Nigeria and UEMOA countries reinforces the informal trade between Nigeria and its neighbours. This pushes huge numbers of individual and especially small business traders into using the parallel and poorly regulated informal currency market - where they can convert CFA francs to naira, or vice versa, without difficulty, as required to pay foreign suppliers or convert income from foreign sales into their own currency. Once a new business starts 
to handle its transactions through the parallel currency market, it becomes easier to keep many other dimensions of economic activity including value addition in the informal space and this may, for example, mean that business growth and productivity is entirely unaccounted for in the domestic tax system.

This is an incongruous situation, given the well-established nature of both the naira and the CFA franc which are regarded as fundamentally credible by traders and consumers in West Africa. The trust placed in these currencies underpins a well-functioning informal exchange market between Nigeria and its neighbours. In this parallel market, there is little to no difficulty in exchanging naira for CFA francs or vice-versa, and traders selling or buying goods across the borders routinely negotiate and agree prices in either currency.

However, for reasons of monetary and exchange rate policy, the CBN and the Central Bank of West African States (BCEAO) impose exchange rate rules that make it almost impossible, in practical terms, to directly convert these currencies through the officially regulated local banking system. To do so, businesses are forced to formally process transactions through the international hard currency foreign exchange market. Direct conversions between the naira and CFA franc are in fact feasible and would not pose a major technical problem for West African banks (Hoffmann and Melly, 2015). Existing obstacles are regulatory rather than technical or economic.

Current central bank policy thus has the effect of undermining the wider, long term goal of ECOWAS member states who seek to forge a more integrated regional economic space that will foster the growth of formal trade between member states, with consequent benefits for growth, livelihoods and government revenues (Musuku, Malaguti, Mason and Pereira, 2012:55-63; Rippel, 2012: 73-85).

Financial regulators have permitted a number of West African banks to expand beyond their home markets and open branches or subsidiaries in other ECOWAS states. However, West African governments have failed to create a regional payments infrastructure appropriate to the needs of most small- and medium-sized local businesses engaged in cross-border trade - who do not have the need, or indeed the managerial and technical resources to deal with the foreign exchange system.

The present situation forces SMEs to choose between assuming the cost and huge administrative burden of dealing with the foreign exchange market or operating informally. This places them at a competitive disadvantage to larger competitors who are, of course, formally registered and do have the means to deal with the foreign exchange system. This is a particular problem for SMEs engaged in local production using local raw materials but facing competition from large importers bringing in cheap rival products from outside West Africa.

For example, a northern Nigerian trader buying dates or sesame from Niger for sale locally in Kano has revenues in naira but in reality needs to pay Nigerien suppliers in Niamey or Maradi in CFA francs, while a Beninese consumer goods distributor buying Nigerian manufactured kitchen utensils has revenues in CFA francs but also needs to pay the Lagos supplier in naira. At this local/regional level, the participants in trade are not using "hard" currencies such as the euro or dollar at all. Yet the CBN/BCEAO ban on direct formal local cross-border naira/CFA franc transactions means that these local traders cannot make their payments and purchases in these local currencies through the formal banking system.

Briefly in early 2015, at least two Nigerian banks tried to develop a response to this problem. They identified an apparent gap in the rules that did allow them to establish simple and efficient low-cost services for cross-border electronic payments. These services were low cost and enabled traders to effectively send payments from CFA franc to naira or viceversa through bank electronic payment systems that provided a transparent record of 
transactions and the movement of money across borders. With their modern treasury IT systems, the banks managed the onward international currency market reflection of these local West African transactions. However, within months the central banks had ordered the shutdown of these new bank services. They argue that they must maintain the ban because they need to effectively control and supervise cross-border payments as a support to national monetary policy and a weapon against criminality and money-laundering.

\section{Tariff regimes}

Since the 1990s, relations between countries in ECOWAS have been characterised by a steadily deepening political partnership in addressing threats to regional security and in reinforcing democratic governance (Walther, 2018). However, progress towards regional economic integration has lagged with persistent differences between countries. Differences relating to tariff, infrastructure, monetary policy and other regulatory conditions encourage the circumvention of administrative and fiscal hurdles that add cost and hassle to trading between ECOWAS member states on a formal basis. This border effect on trade is especially true of Nigeria.

The tariff regime differs significantly from the national tariff rates applied by countries outside of UEMOA, for example Nigeria, which apply higher tariffs on a range of items including vehicles, rice and tomato concentrate. This tariff difference combined with the huge size of Nigeria's domestic market and its high imports profile, make it a magnet for businesses looking to take advantage of the surrounding lower tariffs and better shipping-related infrastructure.

It creates a powerful incentive for traders to channel imports from the rest of the world into Nigeria via Cotonou, the main port in Benin, which has consistently recorded higher efficiency rates than Nigeria's seaports in Lagos. Typically, goods are landed in Cotonou and formally declared as imports into Benin itself, and thus tariffs are levied at the lower UEMOA rates. However, after the goods have entered Benin they are smuggled into Nigeria informally, where they can be sold more cheaply.

Changes to the regional context following the implementation of the CET, a single tariff regime to be applied by all member states to imports from the rest of the world, were expected to erode one of the major drivers behind the flow of informal trade from the Cotonou conurbation into southwest Nigeria by lowering the incentives for import duty shopping and cross-border smuggling. However, the CET process is still far behind the intended level of tariff harmonisation. At the time of the adoption of the CET, it was clear that the new regime would not be implemented immediately and in full. For Nigeria, implementation of the CET was stalled because of the 2015 national elections and the change in administration. ${ }^{5}$ In the context of Nigeria's undiversified economy, the full benefits of reducing import duty rates on specific items are constrained by persistent challenges such as the unavailability of foreign exchange, corruption, low productivity and poor national infrastructure.

\section{Smuggling of vehicles}

One of the largest flows of informal import trade through Benin and across the land border into Nigeria over recent years has been vehicles, particularly used cars imported from other parts of the world (Beuving, 2015). After being imported into Benin, many of these vehicles are taken into Nigeria informally while a lesser number are officially re-exported across the border.

However, the slump in the buying power of the consumer economy during 2016 dealt a severe blow to this traffic: far fewer Nigerians could afford to buy cars, used or new. The flow of vehicles through Cotonou plunged from an estimated monthly average of around 30000 to a mere 6000 in December 2016. 
A further blow to the trade flow was struck when Nigeria's President Muhammadu Buhari announced a ban on the import of new used vehicles by road to take effect on 2 January 2017. The measure may have been aimed at bolstering trade — and customs revenue through Nigeria's own ports, creating a more favourable environment for the revival of Nigeria's own vehicle assembly sector and applying a squeeze on the non-essential import of vehicles at a time when hard currency is in short supply.

By late January, the impact of the vehicle import ban was being severely felt by car dealerships in Cotonou and Nigeria and more widely in the local business community. Many of the Lebanese traders involved in the vehicle sector have shut down their operations and left the country.

So far the ban has had very little impact on increasing domestic assembly of cars in Nigeria but industry experts claim a noticeable increase in smuggled cars into Nigeria from neighbouring Benin and Niger.

\section{The fuel business}

While the vast Nigerian market, with more than 180 million people, has a large appetite for imports, it is also the source of major informal trade flows - of which fuel may be the most significant.

Nigeria has a long history of subsidising the retail price of refined fuel. This has traditionally been intended for the domestic public to reap a direct benefit from the country's status as a major oil producer. Fuel subsidies have had an impact on the economy within Nigeria, and the subventions have also represented a substantial cost for the federal government. But there have been consequences for regional neighbours too.

The fuel available in Nigeria at a cost well below open world market levels is, of course, also attractive to consumers in neighbouring Benin and Niger who must otherwise buy their supplies from domestic formal sector retailers at unsubsidised prices based on the world market. A massive cross-border informal trade in cheap Nigerian fuel has developed in response to this imbalance, with large volumes being moved across the border on barges using coastal creeks, in tankers and on trucks using back roads and, most visibly, on motorbikes loaded with jerry cans, which use the main highways until they are close to the border before diverting onto side trails and tracks through the countryside.

In Benin, this smuggled fuel is sold at the roadside in informal fuel kiosks. The trade is completely open and Beninese authorities have made no serious effort to impede it, despite concerns about the health and safety of the conditions in which it is traded. Developments in Nigeria, however, have brought significant changes to the economics of fuel trading with its neighbours.

The slump in world oil prices from mid-2014 onwards reduced the open market cost of fuel, thus narrowing the gap between subsidised prices and the level at which prices would have settled if fuel was sold in Nigeria on a purely commercial basis. This has made it easier for the Nigerian government to envisage scrapping the subsidies - a move that was met with fierce protests in 2012 (Ejue and Okeyim, 2013). Conditions became, however, more favourable and so, in mid-2016 the government announced the removal of fuel subsidies, a move that increased the retail cost of petrol from naira 87 per litre to naira 145.

This of course meant that the fuel also became much less price competitive, so there was less incentive to informally traffick it into Benin. However, over the years, smuggled fuel - kpayô — has become an integral part of the domestic Beninese energy economy. 
Moreover, the country has experienced several episodes of supply shortages and the formal sector remains underequipped to fully satisfy demand. Even six months after the Nigerian government's abolition of fuel subsidies, fuel smuggled from Nigeria was still accounting for a large proportion of supplies to personal consumers in Benin. Therefore, the reduction in fuel subsidies may have had some impact on smuggling into Benin, but that impact does not yet seem to have been totally decisive and Nigerian fuel still appears to be a relatively attractive commodity in the Benin market.

\section{Food production, trade policy and tariffs in Nigeria: The example of rice}

Over recent years Nigeria has attempted to use trade policy as a tool to support the national drive to reinvigorate agricultural production, particularly the farming of rice. It has experimented with both fiscal measures, such as a rice levy, and quantitative controls, in an attempt to limit the flow of imported rice into the domestic market, and thus to indirectly stimulate demand for locally produced rice.

These measures have proved largely ineffective, because rice is available at relatively low cost on the world market and is easily smuggled — conditions that encourage the import of rice into Benin, from where it is smuggled across the border. The picture is further complicated by the fact that there is a regional market for cereals across West Africa and, under ECOWAS rules, these are not subject to tariffs or customs duties. As with other cereals such as millet, there is scope for the development of a regional West African market in rice produced within member states, with the direction and volume of trade flows responding to seasonal variations in demand and production (as already happens, for example, with trade in millet across the Nigeria/Niger border).

But rice is treated as a more politically sensitive issue, and at times Nigerian federal governments have felt they must adopt a more interventionist approach in their effort to promote local production, even though the ease with which rice can be smuggled means that any such measures face a high risk of failure.

This was a point implicitly conceded by officials of the Customs service in late 2016, when they announced the lifting of a ban on the import of rice. An official spokesman said: "The decision to ban it...was not an effective measure, because smuggling of the product thrives with people using different means of conveyance including small trucks, bicycles and even animals - putting them on donkeys and some actually carry it on their heads (Vanguard Newspaper, 7 October 2015)."

Yet the political sensitivity of the issue was reflected in the government's decision to replace the ban with significant fiscal deterrents to the formally regulated import of rice, by imposing import duty of $10 \%$ and a $60 \%$ levy, while local rice millers would face paying duty of $10 \%$ and a $20 \%$ levy. But the scale of these fiscal imposts could well prove to act as a renewed incentive for rice smuggling. Indeed, informal trafficking could substantially increase because the new existence of a legal internal market in imported rice means that once smuggled consignments have been brought over the border they can simply be released into the domestic market, effectively "laundered" into legality by the country. Once they are in the distribution chain, there is no way they can be identified as having originally been smuggled.

Efforts to curb rice smuggling are unlikely to be effective, given the length of the BeninNigeria border, the numerous official crossing points and the powerful incentive for smugglers created by the new fiscal levies. 


\section{STRENGTHENING NIGERIA AND NEIGHBOURING COUNTRIES' BUSINESS-ENABLING POLICIES}

\section{Regulations and reforms}

$\mathbf{R}$ ecent improvements in the Nigerian business environment have been reported by the World Bank (2017) in its latest report on "Doing Business". The regulatory reforms that have made this success possible are significant. Yet the key challenge the country faces is that of ensuring that current reforms are irreversible and critical efforts are made to deepen progress. This cannot however be achieved without a strong shift in the way Nigeria's regulatory, trade and tax agencies “think” about business in Nigeria.

This means that reform efforts must be guided by a broadened, joined-up strategy shared by all the agencies that have an impact on the real and long-standing challenges of doing business in Nigeria. The approach needs to carefully consider the needs of not only foreign investors and businesses, but also local businesses. As evidenced by the restrictive and counterproductive nature of the country's monetary policy since 2016, too often, government actions are disconnected from the real conditions that make it difficult for the average business person in Nigeria - particularly small and medium entrepreneurs -to regularly make a profit, grow their business, add value, employ more people, as well as provide benefits to their employees and secure business insurance.

If national policymaking was framed by an understanding of these conditions, then government actions could be better designed and planned to account for the roughly $64 \%$ of the country's GDP which is generated in the informal economy. This percentage represents Nigeria's real economy which is made up of real people with entrepreneurial ideas and drive. A hard look at the areas of progress in the World Bank's report reveals that more is still done to create an enabling environment for foreign direct investments (FDI). Foreign investors are more often interested in the prospects and opportunities for Nigeria's extractive industries -- rather than the non-extractive sectors that actually create more jobs and lead to more shared prosperity.

\section{Insufficient public investment in public goods and services}

The long years of weak public investment in public goods and services such as roads, housing, education and health, and a reliance on private investment in some cases, have contributed to a strong self-sufficiency mind-set among Nigerians. It helps to explain the challenges of raising revenue domestically from taxes.

For instance, less than $50 \%$ of the population has regular access to power. Yet if Nigeria intends to pursue a path of economic recovery and growth then the country as a whole must be brought out of the dark and into the light. The inadequate availability and the high cost of electricity in Nigeria hamper the growth of SMEs and contribute to the overall high cost of doing business -- and this undermines entrepreneurs' willingness to pay taxes or declare the true size of their business operations to authorities.

Shortcomings in transport infrastructure impact the cost of moving goods and thus further undermine traders' willingness to formalise their status and thus become subject to official taxes and regulation. Public trust is a fundamental prerequisite for effective tax collection which is the key source of revenue for government spending on public goods and services. Without it, the universal social contract is trapped in a vicious cycle. However the state authorities in Lagos, one of the region's largest commercial hubs, have shown that through direct engagement with entrepreneurs, it is possible to build trust and expand the tax base by persuading informal businesses that it is in their own economic interest to formalise (Gramont, 2015: 10-17). 
Public trust also depends on transparency. The agencies that engage with businesses, ranging from product standards regulation to customs, need to operate in a manner that is open and accountable. This also reduces corruption because it exposes the many opportunities for rent-seeking, extortion and bribery to proper scrutiny and government agents are less inclined to be corrupt in a transparent system.

Elaborate bureaucracy can put pressure on people to engage in corruption, paying to cut corners or overcome bottlenecks. By contrast, procedures that are transparent and simplified encourage formalisation because they are easier and cheaper to deal with and more likely to earn the trust of businesspeople. In practical terms, this means simplified tax filing systems and more one-stop border posts — so that trade and border management agencies act as checks on each other - and clear information on procedures, to encourage compliance.

\section{The role of port infrastructure and efficiency in international trade}

The main ports in Lagos, Apapa and Tin Can Island, have in the past suffered from serious infrastructure constraints, and relatively high costs and long processing times for the clearance of cargo. Consequently, many importers prefer to land cargo in Cotonou and then bring it into Nigeria by road, either through formal import channels or else informally as smuggled trade.

In the past, Lagos ports were also notorious for corruption, massive inefficiencies and lengthy delays in berthing and unloading vessels. These problems were particularly severe in the 1980s and 1990s.

In more recent years, and particularly since the transfer of Apapa and TinCan to private concession management in 2005, huge efforts have been made to improve the performance of both ports. The operating companies, APM Terminals (Apapa) and Bolloré (TinCan) have invested heavily in equipment and introduced modern management systems, while Nigeria Customs Service (NCS) has substantially upgraded its systems, notably through the introduction of online platforms to perform much of the documentary clearing process that must be completed while cargo is still on ships sailing towards Nigeria.

However, both ports continue to be hampered by their geographical location on the southern shoreline of the sprawling Lagos conurbation. Vehicle access and the movement of cargo out of the port areas is hindered by the city's notorious traffic jams; space is also at a premium, because the ports are surrounded by urban areas.

Cotonou port, being in a much smaller city, is considerably more accessible. Costs for the storage of cargo or, for example, power supply to refrigerated containers, are relatively low. The Cotonou port is also equipped with two container terminals, operated by APM and Bolloré, and the latter's terminal has three berths equipped with modern gantry cranes, for the rapid unloading of containers; this is crucial in serving large deep-sea container ships, whose operators seek to keep time in port to a minimum.

Faced with this situation, investors and the federal government of Nigeria have begun to develop plans for the development of new port facilities outside central Lagos. APM drew up plans for a new container terminal at Badagry, west of the city, while a second group of investors has been developing a major new container port at Lekki, east of the city. Both these new projects would be equipped with the most modern cranes and handling systems and served by road links circumventing most of Lagos, allowing relatively smooth onward transport to other destinations in Nigeria. 
However, both projects have been beset by delays and uncertainties. In August 2016, President Muhammadu Buhari gave the official go-ahead for the Badagry development, but some commentators have raised questions about its viability in the current depressed state of the Nigerian economy.

These developments, among other wider issues, have consequences for the Beninese economy. Already, the introduction of the CET, the slowdown in the Nigerian economy since 2015 because of weak oil prices, changed rules on vehicle imports and Nigeria's introduction of regular container rail services from Lagos to Kano, have seriously begun to erode the flow of freight through Cotonou.

\section{Land transport infrastructure and connectivity in trade}

The infrastructure for transporting goods onwards from the port of arrival is another factor that influences trade flows, including the weight and proportion of trade that flows through informal channels.

A significant proportion of the trade between the outside world and landlocked northern Nigeria - and particularly Kano, a major city and economic hub - actually flows through Benin. The volumes of trade concerned are significantly influenced by the quality of land transport links, either internally within Nigeria, from Lagos to Kano, or on the alternative route from Cotonou north to the Benin-Niger border at Malanville/Gaya.

Goods imported via this latter route are then transported onwards by truck, on Niger's relatively good road network, to the Nigerien city of Maradi, which is only a few hours' drive from Kano. The route from the coast to Kano via Benin is longer than the more geographically direct route within Nigeria, from Lagos to Kano. However, in terms of time and cost, the Benin route can be competitive, because of the faster and cheaper transit of cargo through Cotonou port and the relatively straightforward access from the port to the main northbound highway, to Parakou and, eventually, Malanville. However, road conditions within Benin used to be relatively good, but because of poor maintenance, the journey is arduous. Moving goods out of Apapa or Tin Can and across Lagos can be a slow process, because the city road network is so overburdened. The picture is evolving because of the changing condition of transport networks within both countries.

In Nigeria, sections of the northbound route, notably from Abuja to Kaduna, have now been substantially upgraded. Rail transport is also becoming a factor. Regular container trains now run from Lagos north to Kano, offering both smoother transit and much enhanced security. An inland dry port is also being developed at Kano while a port in neighbouring Kaduna has commenced operations. This means that containers can now move from Lagos under customs bond all the way to Kaduna (and eventually to Kano), before clearing customs procedures.

Meanwhile, in Benin, a long-neglected rail network is also scheduled for upgrade: the aim is to revamp the run-down domestic line from Cotonou to Parakou and extend this to Niamey, in Niger and then on to Ouagadougou in Burkina Faso where it will link up with the railway from Abidjan. The route could potentially carry containers from Cotonou to southwest Niger and onwards by road to destinations in northern Nigeria.

The French logistics group Bolloré initially proposed this loop and started work, building an initial $140 \mathrm{~km}$ Nigérien section of line south from Niamey. ${ }^{6}$

\section{Land border procedures and informality}

A further inhibition to the formalisation of trade between Nigeria and Benin has, for many years, been the conditions prevailing at the main border crossing, Semé Kraké, on the Cotonou-Lagos coastal highway - with slow procedures and a poorly organised border 
crossing area. Moreover, for several kilometres on the Nigerian side of the border, vehicles are at high risk of being halted by officials from a wide range of government agencies for repeated checks. Illegal revenue extraction has often been a feature of these checks. Indeed, field research in 2015 revealed stiff competition among officials to secure postings to the Sémé border area because it proved so remunerative. ${ }^{7}$

These constraints have encouraged the informalisation of trade. Many business people feel that if they face the prospect of being forced to make illicit payments in order to ensure the passage of their shipment, then they might as well avoid the official trade corridors and negotiate such payments to secure smooth passage through informal border crossings, without the additional time and cost of completing official frontier procedures.

Such problems, although particularly severe on this corridor, are certainly not unique to the Sémé border crossing and, with European Union support, ECOWAS has begun to establish a number of modern border crossings, where all formalities and checks, by officials from the two countries concerned, are carried out in a single concentrated location. This reduces the scope for officials to engage in illegal harassment or revenue extraction, and makes for greater efficiency. Sémé is one of the crossings that is benefitting from improvements in facilities; the Malanville/Gaya crossing between Benin and Niger, on the route to northern Nigeria, has already been upgraded.

\section{POLITICAL PERSPECTIVES}

nformal trade between Benin, Nigeria and Niger remains dynamic, although patterns in specific sectors can fluctuate in response to regulatory action, shifts in the value of the naira or levels of overall economic activity. However, there could be significant benefits both for government economic management, for consumers and business activity and also for specific individual businesses, if a substantial proportion of the activity that is currently informal did move into the formal realm. Local small businesses that took the formal route could see their ability to compete against foreign imports enhanced, despite the limited additional fiscal or administrative costs that formalisation would entail.

Government and public authorities in Nigeria and neighbouring countries could undertake a number of policy steps that would encourage more businesses to formalise. Some are major policy steps or public investments, with large political or financial implications, but other measures that could have a major impact would cost relatively little or might pose few political or economic complications.

Since 2015, some steps have been taken, but there remains wide scope for further policy actions and public investments, both large and small.

\section{Nigeria should break from a trade policy-framework that depends on protec- tionist measures and import restrictions to address import dependency.}

Nigeria has a long history of trade and industrial policies that have underperformed in achieving the desired goal of expanding local manufacturing and industrialisation. These policies tend to be applied in a manner that contradicts its trade commitments with its regional partners and undermines exports. The country stands a better chance of addressing import dependency through a more competitive and consistent foreign exchange regime. Also because of Nigeria's comparably more advanced industries, it is best positioned to drive regional manufacturing and benefit from a trade environment shaped by the CET. 
Government action should be more informed by the potential of Nigeria's domestic businesses.

Public investment should reflect an understanding of the regulatory and infrastructurerelated difficulties that local Nigerian business people face. That understanding should then lead to policy responses that incentivise them to move their activities into the formal business environment. For as long as it is easier to operate outside the "inconvenience" of government regulation, more and more people will stay in the informal sector which has continued to create more jobs than the formal sector.

\section{Central banks should encourage commercial banks to provide simple electronic services for direct CFA-naira payments.}

The CBN and BCEAO, the central bank of the UEMOA franc zone, should promote procedures to permit commercial banks to offer such direct naira/CFA franc payment services - and indeed, actively encourage banks to do so and diversify their services to consumers. Nigeria could also learn from innovative payment systems being offered in other African countries pursuing trade formalisation i.e. Kenya, Rwanda and Ethiopia building on knowledge exchange between Regional Economic Communities (RECs) such as ECOWAS, the Southern African Development Community (SADC) and the East African Community (EAC).

Authorising and encouraging banks to establish such services would have several benefits. First, smaller businesses that have just local currency revenues and costs would find it easier to buy or sell from neighbouring countries. The option of electronic payment on an affordable and simple basis would also spare SMEs, farmers' co-operatives and individual traders from the physical risks of carrying large volumes of cash - which currently increases their exposure to criminal robbery and to corrupt extortion. In addition, the increased flow of payments through the banking system rather than the informal cash parallel market would give BCEAO and the CBN more accurate information about the movements of money in and out of the monetary zones they regulate. Finally, the existence of easy payment through such a formal scheme could encourage more small businesses and traders to formalise, which would benefit both them and government authorities. Businesses would have easier access to government technical support and to commercial bank credit and support. And because the transactions would be formally declared, governments could more easily apply basic product standards and safety rules — and more easily collect tax revenue from businesses whose activities were now formally declared.

\section{Business facilities for SME and market traders should be improved.}

At relatively low cost, markets important for cross-border trade in Benin, Nigeria and Niger could be equipped with business service facilities that would provide traders with essential services, such as help in completing paper and online documentation, office services such as scanners and computers for emailing documents, and government advice on procedures, official grants, technical advice and so on. It may be that traders and market associations themselves would be willing to contribute to the costs, perhaps through service-use subscriptions or membership fees, but the provision of such services would need to be co-ordinated with relevant government agencies such as the Nigerian Export Promotion Council (NEPC), the Nigeria-Niger joint commission or the Kano-KatsinaMaradi (K2M) corridor authorities.

More integrated one-stop border posts should be established at Nigeria's key frontier crossings with Benin and Niger.

Under an ECOWAS initiative, at a small number of major frontier crossings, the member states concerned have established integrated single-stop border control posts, where all the official procedures of both countries are carried out at a single site equipped with 
modern facilities. This increases efficiency, reduces the time consumed in completing formalities and increases transparency thus curbing the opportunities for corrupt revenueseeking or other illegal behaviour. One of the first such posts was at the Gaya/Malanville border between Niger and Benin, but a modernised post has now also opened at Sémé, the principal Nigeria-Benin crossing. Integrated border posts could also be set up at the Nigeria-Niger border, just north of Jibia - on the key K2M axis between Kano, Katsina and Maradi - and at Ilela/Birnin Konni, on the route from Sokoto to Niamey and to Tahoua; and perhaps also on the route from Kano to Zinder. The creation of an integrated one-stop crossing point at Jibia is particularly important, given all the effort that is now being devoted to the promotion of trade between Nigeria and Niger through the K2M corridor. On the Benin-Nigeria border, there is surely scope to open one or two additional one-stop modernised border posts in addition to Sémé, to facilitate formal trade between central and northern regions of the two countries.

\section{The governments of Benin, Nigeria and Niger should try to facilitate the completion of new port and rail infrastructure.}

The construction of the new rail line from Cotonou to Niamey would support the development of a more competitive and dynamic trading environment. Major infrastructure investments would enhance the inflow and outflow of formal trade through Lagos port, thus stimulating competition with Cotonou, while the completion of the Benin-Niger rail link would strengthen Cotonou's capacity to act as an alternative competing trade gateway for northern Nigeria.

Moreover, improvements to local infrastructure, such as lorry parks serving ports and markets and cross-border roads, are crucial and would improve trading efficiency. In particular, there is a strong case for the creation of modern border markets at key frontier trading centres such as Ilela/Birnin Konni.

\section{NOTES}

1 For more information on the ECOWAS Trade Liberalization Scheme, please see http://www.etls. ecowas.int

2 Interviews with authors under the Chatham House Rule, Kano, Lagos and Cotonou, March and June 2015.

3 UNFPA estimate of population in 2016. United Nations and Africapolis figures suggest that Nigeria's urban population reached 50 million by the year 2000 and 77 million in 2010.

4 Following the Malabo Declaration of June 2014, the Permanent Inter-State Committee for Drought Control in the Sahel (CILSS) regularly collects data on a number of agricultural trade flows including livestock at key border crossings in the region. See CILSS's monthly bulletin of Intra-Regional Commodities Trade of Agriculture and Livestock in the Sahel in West Africa.

5 It was only in 2016 that the current administration approved the Fiscal Policy Measures which allow the implementation of the Supplementary Protection Measures under the CET regime for the period of 2015 through to 2019.

6 However, Bollorés right to develop the Benin section was challenged by the businessman Samuel Dossou and the Benin courts froze work on the project. Legal battles continue to stall the project. Benin's President Patrice Talon appears to have concluded that it would be better to hand the project over to the Chinese. In March 2018 he called on both Bolloré and Dossou to withdraw, arguing that China had the capacity to complete the project. RFI Afrique, 23 March 2018.

7 Interviews with authors under the Chatham House Rule, Lagos and Cotonou, March - June 2015. 


\section{REFERENCES}

Amin, M. and M. Hoppe (2013), “Where Informal Procedures are Quasi-Formal - Cross-Border Trade between West and Central Africa", Africa Trade Policy Note, No. 37, The World Bank, Washington DC.

Asiwaju. A.I. and P.O. Adeniyi (1989), Borderlands in Africa: A Multidisciplinary Focus on Nigeria and West Africa, University of Lagos Press, Lagos.

Atkin, D. and D. Donaldson (2015), “Who's getting globalized? The size and implications of intra-national trade costs", Working Paper No. 21439, The National Bureau of Economic Research (NBER), July.

Benhassine, N. et al. (2016), "Can enhancing the benefits of formalization induce informal firms to become formal? Experimental evidence from Benin", Working Paper No. 7900, World Bank Group Policy Research, November.

Beuving, J. (2015), “American cars in Cotonou: Culture in African entrepreneurship and the making of a globalising trade", The Journal of Modern African Studies, Vol. 53/3, pp. 317-338.

Birdsall, N. (2003), Asymmetric Globalization: Global Markets Require Global Good Politics, Brookings Institute, www.brookings.edu/articles/asymmetric-globalization-global-markets-require-good-global-politics.

Cantens, T. and G. Raballand (2017), "Insecurity and the role of custom: Some lessons from six field studies in (post)-conflict regions", ICTD Working Paper No. 67, Institute of Development Studies.

Cantens, T. (2015), “Un scanner de conteneurs en ‘Terre Promise' camerounaise : adopter et s'approprier une technologie de contrôle", L'Espace Politique, 25, Vol. 2015-1, http://journals.openedition.org/ espacepolitique/3415.

Christensen, B.V. and C. Upper (2017), “Building Resilience to Global Risks: Challenges for African Central Banks", BIS Papers No 93, Bank of International Settlements.

Ejue, J. B. and M. Okeyim (2013), The Ideas and Vision of the 2012 Street Protest in Nigeria, Journal of Sociology and Social Work, 1(1), 9-21.

Golub, S. (2015), "Informal Cross-Border Trade and Smuggling in Africa”, in O. Morrissey, R. A. Lopez and K. Sharma (eds), Handbook On Trade And Development, Edward Elgar

Gramont, D. (2015), “Governing Lagos: Unlocking the Politics of Reform”, Carnegie Endowment for International Peace Report, January, https://carnegieendowment.org/files/governing_lagos.pdf.

Gyimah-Brempong K., M. Johnson and H. Takeshima (2016), The Nigerian Rice Economy: Policy Options for Transforming Production, Marketing and Trade, University of Pennsylvania Press.

Hashim, Y. and K. Meagher (1999), “Cross-Border Trade and the Parallel Currency Market - Trade and Finance in the Context of Structural Adjustment. A Case Study from Kano, Nigeria", Nordiska Afrikainstitutet Research Report No.113.

Hoffmann, L. and P. Melly (2015), Nigeria's Booming Borders: The Drivers and Consequences of Unrecorded Trade, Chatham House Report, December, www.chathamhouse.org/sites/files/ chathamhouse/publications/research/20151207NigeriaBoomingBordersKoniHoffmannMelly.pdf.

Miles, W.F.S. (2015), Hausaland Divided, Cornell University Press.

Musuku, T.B, M. Malaguti, A.M. Mason and C. Pereira (2012), "Lowering the Cost of Payments and Money Transfers in UEMOA" in P. Brenton and G. Isik (eds), De-Fragmenting Africa. Deepening Regional Trade Integration in Goods and Services. World Bank Publication.

Nigerian National Bureau of Statistics (2014), Nigerian Manufacturing Sector Summary Report: 20102012, www.nigerianstat.gov.ng/download/260.

Omoniyi, O.O. (2004), The Sociolinguistics of Borderlands: Two nations, one community, Africa World Press.

PwC (2017), Paying Taxes 2018, PricewaterhouseCoopers and World bank Group, https://www.pwc. com/gx/en/paying-taxes/pdf/pwc_paying_taxes_2018_full_report.pdf.

Rippel B. (2012), “Why Trade Facilitation is Important for Africa”, in P. Brenton and G. Isik (eds), De-Fragmenting Africa. Deepening Regional Trade Integration in Goods and Services, World Bank Publication. 
RFI Afrique (2018), “Le Bénin veut voir Bolloré et Pétrolin sortir du projet de boucle ferroviaire”, 23 March 2018, http://www.rfi.fr/afrique/20180323-benin-talon-demande-retrait-bollore-petrolinprojet-boucle-ferroviaire.

Torres C. and J. Seters (2016), “Overview of trade and barriers to trade in West Africa: Insights in political economy dynamics, with particular focus on agriculture and food trade", ECDPM Discussion Paper No. 195, July.

United Nations (2014), World Urbanization Prospects: The 2014 Revision, Department for Economic and Social Affairs, United Nations, New York.

Vanguard Newspaper (2015), "Customs order immediate removal of restriction on rice import", 7 October 2015.

Verick, S. (2006), “The Impact of Globalization on the Informal Sector in Africa”, United Nations Economic Commission for Africa and Institute for the Study of Labour, Economic and Social Policy Division, Addis Ababa, http://conference.iza.org/conference_files/worldb2006/verick_s872.pdf.

Walther O. (2015), "Business, brokers and borders: The structure of West African trade networks", Journal of Development Studies, Vol. 51/5, pp. 603-620.

Walther O. (2018), “Regional integration and cross-border cooperation", in T. Binns, K. Lynch and E. Nel (eds), Handbook of African Development, Routledge, London.

World Bank (2016), Doing Business 2017: Equal Opportunity for All, A World Bank Group Flagship Report, 14 ${ }^{\text {th }}$ Edition, http://www.doingbusiness.org/ /media/WBG/DoingBusiness/Documents/ Annual-Reports/English/DB17-Report.pdf.

\section{Further reading}

Afrika, J. and G. Ajumbo (2012), "Informal Cross Border Trade in Africa: Implications and Policy Recommendations", Africa Economic Brief, Vol. 3/10, African Development Bank.

Brenton, P. et al. (2011), “Risky business: Poor women cross-border traders in the Great Lakes Region of Africa", Africa Trade Policy Note, No. 11, The World Bank Group.

Charmes, J. (2006), "Measurement of the contribution of informal sector and informal employment to GDP in developing countries: Some conceptual and methodological issues", paper presented at the $9^{\text {th }}$ Meeting of the Delhi Group on Informal Sector Statistics, 11-12 May, Delhi, India.

Jawando, O.J, O.E. Adeyemi and O.B. Laguda (2012), “Survival strategies of women in informal crossborder trade along Lagos-Seme Border", Global Journal of Human Social Science-Sociology, Economics \& Political Science, Vol. 12/9, Version 1.0, https://globaljournals.org/item/613-survival-strategies-ofwomen-in-informal-cross-border-trade-along-lagos-seme-border-axis.

Lesser, C. and E. Moisé-Leeman (2009), "Informal cross-border trade and trade facilitation reform in sub-Saharan Africa”, OECD Trade Policy Working Papers, No. 86, OECD Publishing, http://dx.doi. org/10.1787/225770164564.

UNECA (2013), "Report on the Magnitude of and Tools for Measuring Informal Cross Border Trade in Africa's Regional Economic Communities", presented to the $8^{\text {th }}$ Session of the Committee on Trade, Regional Cooperation and Integration, 6-8 February, United Nations Economic Commission for Africa, Addis Ababa, Ethiopia, http://hdl.handle.net/10855/22135.

UNECA (2012), “A Gender Assessment of African Regional Economic Communities Database to Identify Gaps in Capturing the Activities of Women in Informal Cross Border Trade", United Nations Economic Commission for Africa, https://ecastats.uneca.org/acsweb/Portals/0/Publications/DSS/ Gender\%20assessment\%20EN.pdf.

UN Women (2010), “Unleashing the potential of womeniInformal cross-border traders to transform intra-African trade", www.unwomen.org/en/digital-library/publications/2010/3/unleashing-thepotential-of-women-informal-cross-border-traders-to-transform-intra-african-trade. 


\section{ALSO IN THE WEST AFRICAN PAPERS SERIES:}

Allen, T. and P. Heinrigs (2016), “Emerging Opportunities in the West African Food Economy", http://dx.doi.org/10.1787/5jlvfj4968jb-en

Lewis, K. and C. Buontempo (2016), "Climate Impacts in the Sahel and West Africa: The Role of Climate Science in Policy Making", http://dx.doi.org/10.1787/5jlsmktwjcd0-en

Gnisci, D. (2016), “Women's Roles in the West African Food System: Implications and Prospects for Food Security and Resilience", http://dx.doi.org/10.1787/5jlpl4mh1hxn-en

Staatz, J. and F. Hollinger (2016), "West African Food Systems and Changing Consumer Demands", http://dx.doi.org/10.1787/b165522b-en

Prieto Curiel, R., P. Heinrigs and I. Heo (2017), “Cities and Spatial Interactions in West Africa: A Clustering Analysis of the Local Interactions of Urban Agglomerations",

http://dx.doi.org/10.1787/57b30601-en

Walther, O. (2017), "Cross-border Co-operation Networks in West Africa", http://dx.doi.org/10.1787/73298292-en

Ibrahim, I.Y. (2017), “The Wave of Jihadist Insurgency in West Africa: Global Ideology, Local Context, Individual Motivations",

http://dx.doi.org/10.1787/eb95c0a9-en

Allen, T. (2017), "The cost of high food prices in West Africa",

http://dx.doi.org/10.1787/c2db143f-en

Van Den Hoek, J. (2017), "Agricultural market activity and Boko Haram attacks in northeastern Nigeria", http://dx.doi.org/10.1787/13ba9f2e-en

Walther, O. (2017), "Wars and Conflicts in the Sahara-Sahel", http://dx.doi.org/10.1787/8bbc5813-en

Elisher, S. (2018), “Defying the Odds? Nigerien Responses to Foreign and Domestic Security Challenges",

https://doi.org/10.1787/104d1c6d-en

Eizenga, D. (2018), “The Unstable Foundations of Political Stability in Chad", https://doi.org/10.1787/508844d3-en

Bouchama, N., et al. (2018), “Gender Inequality in West African Social Institutions", http://dx.doi.org/10.1787/fe5ea0ca-en

Allen, T., P. Heinrigs and I. Heo (2018), "Agriculture, food and jobs in West Africa", https://doi.org/10.1787/dc152bc0-en

van Wesenbeeck, Cornelia F.A. (2018), “Disentangling Urban and Rural Food Security in West Africa", https://doi.org/10.1787/e0c75266-en

For more information on the series, please contact: lia.beyeler@oecd.org

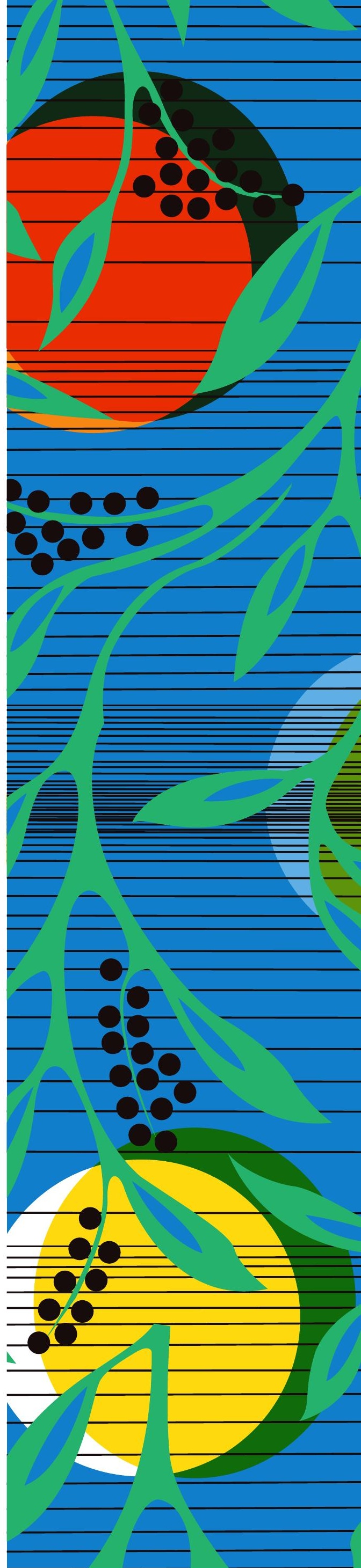

